\title{
Decapod crustaceans from the Kimmeridgian of Bure (Meuse, France)
}

\author{
Gérard Breton ${ }^{1}$, Cédric Carpentier ${ }^{2}$, Vincent Huault ${ }^{2}$ \& Bernard Lathuilière ${ }^{2}$ \\ ${ }^{1}$ Muséum d'Histoire naturelle, Place du Vieux-Marché, F-76600 Le Havre, France; ${ }^{2}$ Université Henri \\ Poincaré Nancy 1, BP 239, F-54506 Vandoeuvre-lès-Nancy cedex, France
}

Keywords : Decapoda, Axï̀dae, Erymidae, Paguridae, Kìmmeridgian, France

\begin{abstract}
Wells being dug at Bure, France, in strata of Kìmmerìdgian age have uncovered a diverse fauna of reptant decapods.
\end{abstract}

\section{Introduction}

ANDRA, the French National radioactive waste management agency, is currently constructing two large wells at Bure (Meuse, France) with diameters of 5 to $6 \mathrm{~m}$ and an expected final depth close to $500 \mathrm{~m}$, in order to create an underground research laboratory. Recently, depending on progress of construction, three of us (CC, $\mathrm{VH}, \mathrm{BL}$ ) have been collecting fossils from the site, from deposits extracted in slices of about $2 \mathrm{~m}$ in thickness. The construction of these wells represents a unique opportunity to compare various subsurface observations (sedimentology, paleontology, geochemistry) on a single vertical, similar to an outcrop. Strata which have provided decapod crustacean remains are all of Kimmeridgian age (Cymodoce Zone or Mutabilis Zone [Marnes à exogyres inférieures] up to the ?Autissiodorensis Zone [lower part of Calcaires du Barrois]; compare Groupe Français d'Étude du Jurassique (1997)). All material is housed in the collections of the Museum-Aquarium at Nancy, under registration numbers MAN 11700 to 11762.

\section{Systematics}

The material comprises the following taxa:

Superfamily Thalassinoidea Latreille

Family Axiidae Huxley

Genus Etallonia Oppel (= Protaxius Beurlen)

Etallonia isochela (Woodward, 1876). (Fig. 1)

About thirty specimens are available from the Cymodoce up to the ?Autissiodorensis zones; propodus flat $(L / 1=1.8-2.15)$, shape rectangular, finger triangular, stocky and quite regularly oriented downwards; chela subcheliform; dactylus 1.5 times longer than finger. In $\mathbf{5 0 \%}$ of specimens fingers show a tubercle at mid-length; we suggest this to possibly represent a sexual character. In associated pairs, anisochely is very moderate, similar to the type specimen.

During preparation, several propodi developed a color pattern when water, acetone or a protective varnish coating was applied. This pattern showed the two following extremes:

- an 'atoll-like' ornament, often centered on small pits (setae insertions?);

- a "flame-like" ornament, associated with very weak elevations.

As preserved, propodi are flattened on bedding planes; occasionally two chelipeds of the same individual are found associated. Calcification de. creases from the propodus to the carpus and merus; the latter is rarely preserved. Of the remainder of the animal nothing is ever preserved. In some cases, 


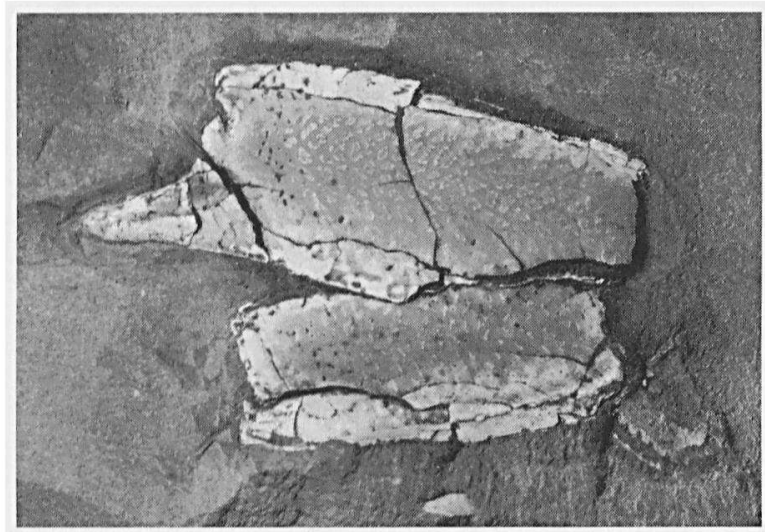

Fig. 1. The axiid Etallonia isochela (Woodward, 1876), associated pair of chelipeds (MAN 11718) with preserved colour pattern (length of propodus $17 \mathrm{~mm}$ ), PAX 1013 (1), co-ordinates $\mathrm{x}=$ 823.151; $\mathrm{y}=1091.639 ; \mathrm{z}=339.56$; Kimmeridgian (Eudoxus Zone, Contejani Subzone).

fossils are disturbed and remains scattered by the action of scavengers and/or burrowers. Color pattern preservation is consistent with low-oxygen levels as deduced from other factors (pyrite, organic matter content).

Superfamily Paguroidea Latreille

Family Paguridae

Genus Palaeopagurus van Straelen

\section{Palaeopagurus sp.}

A single rectangular propodus is available from the Mutabilis or Eudoxus Zone, convex externally, with a short and triangular finger; inner surface of finger concave (spoon like); ornament consisting of tiny tubercles, perforated by setae insertion pits. About ten depressions lining up on external side of finger; a large, circular tubercle at base of finger. Five low, imperforate tubercles on external side of articulation of dactylus. This may represent an undescribed species of Palaeopagurus.

Infraorder Astacidea Latreille Family Erymidae van Straelen Genus Eryma von Meyer

\section{Eryma cf. babeaui (Etallon)}

The posterior portion (right-hand side) of a largely incomplete cephalothorax is here attributed to Eryma babeaui with a query. Size, orientation, and arrangement of preserved portions of furrows as well as density and nature of ornament actually are close to $E$. babeaui, and especially to the specimen described as $E$. leblanci ( $=E$. babeaui) by Sauvage (1891, pl. 4, fig. 6). The present specimen is from the upper Cymodoce or lower Mutabilis Zone.

\section{Eryma ventrosa (von Meyer)}

A posterior fragment of a cephalothorax is available, dorso-ventrally compressed and preserving portions of pereiopods, and a ?cheliped. Size, course of furrows, and ornament allow this specimen to be compared with the lost syntypes of $E$. villersi (Morière), illustrated by Morière (1883, pl. 1), a junior synonym of $E$. ventrosa (von Meyer) (see Förster, 1966). Several fragments of chelipeds, one of which is remarkably similar to a specimen illustrated by Carter (1886, pl. 16, fig. 3) are also available. This material is from the Eudoxus Zone, Caletanum or Contejani Subzone.

\section{Acknowledgements}

The present work has been financially supported by CNRS (Paris) and ANDRA, through the GdR FORPRO (Research action 2001II).

\section{References}

Carter J. 1886. On the decapod crustaceans of the Oxford Clay. Quart. Journ Geol. Soc. Lond. 42: 542-559.

Förster R. 1966. Über die Erymiden, eine alte konservative Familie der mesozoischen Dekapoden. Palaeontographica A125: 61-175.

Groupe Français d'Étude du Jurassique. 1997. Biostratigraphie du Jurassique ouest-européen et méditerranéen : zonations parallèles et distribution des invertébrés et microfossiles. Bull. Centr. Rech. Elf Expl. Prod. Mém. 17: 1-440.

Morière J. 1883. Première note sur les crustacés de l'Ox fordien trouvés dans le Calvados. Bull. Soc. linn. Norm. (3)6: 16I167. 
Sauvage HE. 1891. Note sur les crustacés des terrains jurassiques supérieurs du Boulonnais. Ann. Sci. nat. (7)12: 8396.

Woodward H. 1876. On some new macrurous Crustacea from the Kirmmerídge Clay of the Sub-Wealden boring, Sussex, and from Boulogne-sur-Mer. Quart. Journ Geol. Soc. Lond. 22: 47-50. 